\title{
JENIS AVES DAN MAMALIA DIURNAL YANG MEMANFAATKAN JAMBU TANGKALAK (Bellucia pentamera) SEBAGAI SUMBER PAKAN DI KEBUN RAYA SAMBAS
}

\author{
(Species of Diurnal Aves and Mammals that Use Bellucia pentamera as a Source of Feed at \\ Sambas Botanical Garden)
}

\author{
Aldi Haryono, Hari Prayogo, Erianto \\ Fakultas Kehutanan, Universitas Tanjung Pura, Jalan Imam Bonjol Pontianak 78124 \\ Email: aldisebedang@gmail.com
}

\begin{abstract}
Sambas Botanical Garden is an ex-situ conservation area, in its management there is the term Vak, which is a small management area with care and supervision that is more focused on the inside plants, Bellucia pentamera in the management of Vak is very limited and cut down, but actually Bellucia pentamera is forest plant which has the criteria of providing fruit almost all year long and is widely used by most wildlife. The study aims to record species of aves and diurnal mammals that use Bellucia pentamera as a source of feed for wild animals in the Sambas Botanical Gardens. The research was carried out in the management area and secondary forest, each represented by three growing places, namely hills, foothills and riparians. The study was conducted in July-August with a survey method by observing direct observation at the point of tangkalak guava stands with repetitions three times. The results showed that seven types of aves were found, namely Chloropsis sonnerati, Dicaeum trigonostigma, Dicaeum trochileum, Pycnonotus goiavie, Chloropsis cochinchinensis, Zosterops palpebrosus, and Arachnothera crassirostris, There are four types of mammals found, namely Macaca fascicularis, Sundasciurus lowii, Callosciurus prevostii, and Callosciurus orestes.
\end{abstract}

Keywords: Aves, Bellucia pentamera, Feed, Mammals.

\section{PENDAHULUAN}

Undang-undang Republik Indonesia No. 41 tahun 1999 tentang kehutanan, hutan konservasi adalah kawasan hutan dengan ciri khas tertentu, yang mempunyai fungsi pokok pengawetan keanekaragaman tumbuhan dan satwa serta ekosistemnya. Kebun Raya Sambas adalah salah satu kawasan hutan konservasi yang pengelolaannya termasuk baru, mulai dikelola pada tahun 2008 dengan bimbingan langsung oleh LIPI Bogor.

Pengelolaan kebun raya tidak lepas dari pembukaan vak yang merupakan wilayah atau kawasan kecil yang dikelola dan didalamnya terdapat tumbuhan koleksi, vak dalam istilah kebun raya diambil dari bahasa Belanda yang berarti kotak atau dalam arti lain dapat disebut blok. Tumbuhan koleksi adalah tumbuhan yang dipelihara yang memiliki nilai konservasi. Berlangsungnya pembukaan vak berarti membuka kawasan hutan yang sudah ada menyisakan sebagian tumbuhan asal yang memiliki nilai konservasi, digantikan dengan tanaman yang baru yang didatangkan dari luar sesuai dengan konsep kebun raya yaitu konservasi exsitu.

Pembukaan vak di Kebun Raya Sambas terbilang tidak ramah lingkungan, 
karena saat pembukaan lahan kawasan yang sudah ada tegakannya di tebang seluruhnya atau ditinggalkan sebagian pohon yang dikehendaki. Terdapat banyak pohon yang berpotensi sebagai pohon yang dimanfaatkan oleh berbagai jenis satwa sebagai sumber pakan ditebang karena keberadaannya kurang bernilai konservasi, jika pohon yang dimanfaatkan oleh hewan sebagai sumber pakan ditebang maka akan mengancam keberadaan dari satwa yang memanfaatkan pohon tersebut.

Jambu tangkalak (Bellucia pentamera) atau biasa disebut jambu marekan banyak tumbuh di kawasan Kebun Raya Sambas, tumbuhan ini adalah salah satu tumbuhan yang dalam perencanaan kebun raya tidak menjadi spesies yang memiliki nilai konservasi, sehingga sebagian besar akan ditebang. Jambu tangkalak adalah termasuk tumbuhan yang menghasilkan buah hampir sepanjang tahun, dan buahnya dapat dikonsumsi oleh sebagian besar jenis burung pemakan biji-bijian, buah lunak dan nektar bunga, beberapa jenis tupai juga memanfaatkan buah pohon tersebut serta jenis primata.

Keberadaan jambu tangkalak dinilai penting untuk keberlangsungan ekositem, maka kelestariannya mesti dijaga. Dilihat dari kondisi masih sedikitnya penelitian yang mengarah dari permasalahan yang terjadi, oleh sebab itu penelitian ini dilakukan untuk mendata jenis aves dan mamalia yang memanfaatkan jambu tangkalak untuk bergantung hidup sebagai sumber pakan, dengan harapan data yang diperoleh dapat digunakan sebagi rekomendasi untuk kelestarian tumbuhan yang diamati serta sebagai sarana mengkonservasi jenis aves dan mamalia yang ada di Kebun Raya Sambas

Penelitian ini bertujuan untuk mendapatkan data jenis aves dan mamalia diurnal yang memanfaatkan jambu tangkalak sebagai sumber pakan di berbagai tempat tumbuh (bukit, kaki bukit dan riparian) serta perbandingan data pada area kelola dan area hutan sekunder di Kebun Raya Sambas.

\section{METODE PENELITIAN}

Penelitian dilakukan di Kebun Raya Sambas, waktu pelaksanaan penelitian selama satu bulan pada bulan Juli-Agustus 2018. Alat yang digunakan yaitu binokuler, kamera, camera trap, buku identifikasi, GPS, meteran, dan jamtangan. Objek penelitian adalah jenis-jenis aves dan mamalia diurnal yang memanfaatkan jambu tangkalak sebagai pakan di Kebun Raya Sambas.

Metode yang digunakan dalam penelitian ini adalah dengan metode survey dengan teknik pengumpulan data dengan observasi pengamatan langsung pada titik yang telah ditentukan sebagi objek penelitian.

Berikut adalah lokasi yang akan yang diamati sebagai sampel penelitan:

a. Tegakan jambu tangkalak pada area Vak 1 (kaki bukit) Kebun Raya Sambas.

b. Tegakan jambu tangkalak pada area Vak 2 (bukit) Kebun Raya Sambas.

c. Tegakan jambu tangkalak pada area taman tematik riparian Kebun Raya Sambas. 
d. Tegakan jambu tangkalak pada area riparian hutan sekunder Kebun Raya Sambas.

e. Tegakan jambu tangkalak pada area perbukitan hutan sekunder Kebun Raya Sambas.

f. Tegakan jambu tangkalak pada area kaki bukit hutan sekunder Kebun Raya Sambas.

Analisis data yang digunakan pada penelitian yang akan dilakukan yaitu dengan berbagai tahap sebgai berikut:

a. Penentuan titik lokasi objek tegakan jambu tangkalak pada enam titik lokasi yang berbeda antara area kelola dan hutan sekunder di Kebun Raya Sambas.

b. Penentuan lokasi dideskripsikan sesuai dengan keadaan lokasi tempat tumbuh jambu tangkalak, serta dengan menjabarkan perhitungan tinggi pohon serta diameter batang pohon yang diamati di setiap lokasi yang berbeda. Rumus yang digunakan sebagai berikut (Asy'ari dan karim, 2012):

- Tinggi pohon (Christenmeter) T1C1 $=(\mathrm{TC} \times \mathrm{T} 1 \mathrm{G}) / \mathrm{TG} 1$
Keterangan:

T1C1 = simulasi tinggi pohon (m)

TG1 = skala tinggi pada penggaris (cm)

$\mathrm{K}=$ keliling batang $(\mathrm{cm})$

$\mathrm{D} \quad=$ diameter batang

c. Pengumpulan data dengan cara observasi langsung dilapangan pada setiap titik dengan mengunakan tenda atau bivak pada area pengamatan objek, ditentukan luasan diameter tajuk tangkalak yang digunakan, pengukuran menggunakan perhitungan proyeksi tajuk (Wijayanto dan Rifa'i 2010). Pengukuran ini dilakukan untuk membagi bagian pohon yang dimanfaatkan sebagai sumber pakan (tajuk bagian atas, tajuk tengah dan tajuk bawah, serta bagian batang batang, dan area bawah pohon).

- $\mathrm{D}=\frac{\mathrm{d}_{\mathrm{pa}}+\mathrm{d}_{\mathrm{pe}}}{2}$

Keterangan:

$\mathrm{D}=$ diameter rata-rata tajuk

$\mathrm{d}$ pa $=$ diameter terpanjang

$\mathrm{d}$ pe $=$ diameter terpendek

- Diameter Batang (D) $=K / \pi$

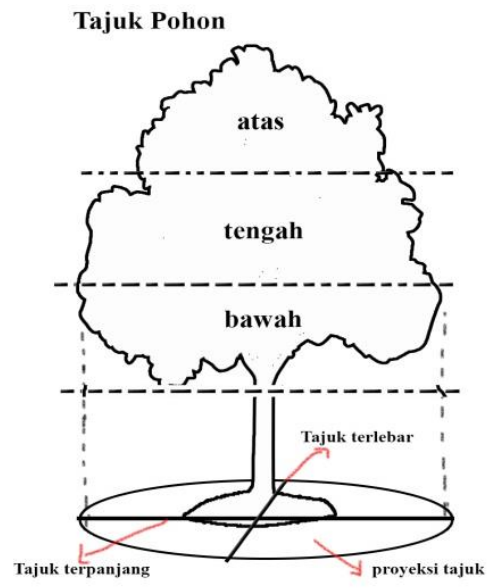

Gambar 1. Perhitungan luasan tajuk vegetasi (Calculation of vegetation canopy area) 
d. Pengamatan dilakukan mulai dari jam 06:00 sampai dengan 17:00 dengan pengulangan 3 kali di masing-masing titik pengamatan dengan rotasi enam hari sekali.

e. Pendataan dengan mengamati, mencatat dan mendokumentasi serta mengidentifikasi jenis aves dan mamalia diurnal yang memanfaatkan tegakan jambu tangkalak sebagai sumber pakan.

f. Mencatat waktu datang hingga pergi dan bagian tumbuhan yang dimanfaatkan oleh satwa serta letak posisi saat kegiatan makan berlangsung sesuai dengan posisi yang lelah dibagi ada proyesi tajuk dengan bantuan Tally Sheet.

g. Penyajian dan analisis data dengan menggunakan deskripsi serta dilengkapi dengan menggunakan bantuan tabel.

\section{HASIL DAN PEMBAHASAN}

Kawasan Kebun Raya Sambas saat ini secara umum merupakan lahan yang ditutupi oleh vegetasi hutan sekunder dan semak belukar. Kondisi vegetasi hutan merupakan tipe hutan dataran rendah dan sedikit hutan rawa dan hutan riparian. Pada penelitian kali ini tegakan yang diamati jambu tangkalak berada pada daerah Area Kelola dan Hutan sekunder dengan lokasi sebagai berikut:

\section{Area Kelola}

a. Tempat tumbuh bukit berada pada Area kelola Vak 2, merupakan lokasi tumbuh jambu tangkalak yang memiliki kerapatan tajuk yang renggang dan merupakan tegakan jambu tangkalak tunggal dan dalam kondisi berbuah. lokasi ini berada 7 meter dari jalan utama menuju ke Mess Kebun Raya Sambas.

b. Tempat tumbuh kaki bukit berada pada Area kelola Vak 1, merupakan tempat tumbuh jambu tangkalak yang memiliki kerapatan tajuk yang rapat berada di daerah kaki bukit dengan tegakan yang rapat disekitarnya dan merupakan tegakan jambu tangkalak tunggal dengan kondisi sedang berbuah.

c. Area riparian merupakan tempat tumbuh jambu tangkalak pada lokasi yang kondisinya dapat tergenang air luapan sungai dan dapat surut sewaktuwaktu. Daerah ini adalah lokasi kelola taman tematik dan berada dekat dengan jalan utama menuju gerbang patok 70 Kebun Raya Sambas. Tegakan yang diamati merupakan tegakan tunggal yang memiliki tajuk desekitar yang rapat dan dalam keadan berbuah, saat pengamatan kondisi air sungai sedang surut.

\section{Hutan Sekunder}

a. Tempat tumbuh kaki bukit merupakan tempat tumbuh jambu tangkalak dengan kerapatan tajuk yang rapat, dengan kondisi tegakan sedang berbuah, berada di jalan sarad menuju lokasi riparian dan merupakan tegakan tunggal yang diamati, terdapat banyak anakan jambu tangkalak di sekitar lokasi dalam keadaan belum berbuah.

\section{b. Tempat tumbuh kaki bukit} merupakan tempat tumbuh jambu tangkalak dengan lokasi di dekat lembah dan memiliki kerapatan tajuk tergolong renggang dengan kondisi 
tegakan sedang berbuah. Jambu tangkalak yang diamati merupakan tegakan tunggal, terdapat beberapa anakan di sekitarnya dalam keadaan belum berbuah.

c. Area riparian merupakan tempat tumbuh jambu tangkalak pada lokasi pasang surut luapan sungai, kondisi tegakan dalam keadaan berbuah dengan kerapatan tajuk tergolong rapat, tegakan yang diamati merupakan tegakan tunggal, keadaan lokasi saat pengamatan dalam kondisi air sungai surut. Lokasi jambu tangkalak yang diamati berada di sekitar jalan sarat menuju sungai subah.

Tabel 1. Data Kondisi Tegakan Tunggal di Setiap Tempat Tumbuh (Single Tree Stand Condition Data at Each Growing Place)

\begin{tabular}{|c|c|c|c|c|c|c|}
\hline No & $\begin{array}{l}\text { Tempat } \\
\text { Tumbuh }\end{array}$ & Lokasi & $\begin{array}{c}\text { Tinggi } \\
\text { Batang }(\mathrm{M}) \\
\end{array}$ & $\begin{array}{c}\text { Diameter } \\
\text { Batang }(\mathrm{Cm})\end{array}$ & $\begin{array}{r}\text { Diameter } \\
\text { Tajuk (M) }\end{array}$ & Titik Koordinat \\
\hline 1 & Bukit & Area kelola Vak 2 & 9 & 27,07 & 3,75 & $109^{\circ} 29^{\prime} 5,643 " \mathrm{E} / 1^{\circ} 16^{\prime} 9,722^{\prime \prime} \mathrm{N}$ \\
\hline 2 & Kaki Bukit & Area kelola Vak 1 & 11 & 22,29 & 3,75 & $109^{\circ} 29^{\prime} 8,575^{\prime E} \mathrm{E} / 1^{\circ} 13^{\prime} 13,575^{\prime N} \mathrm{~N}$ \\
\hline 3 & Riparian & Area taman tematik & 7 & 22,92 & 3,5 & $109^{\circ} 28^{\prime} 43,162^{\prime \prime} \mathrm{E} / 1^{\circ} 16^{\prime} 0,49 " \mathrm{~N}$ \\
\hline 4 & Bukit & Hutan sekunder & 10 & 27,54 & 4 & $109^{\circ} 28^{\prime} 43,931^{\prime \prime} \mathrm{E} / 1^{\circ} 16^{\prime} 23,982^{\prime \prime} \mathrm{N}$ \\
\hline 5 & Kaki Bukit & Hutan sekunder & 7,5 & 23,88 & 3,25 & $109^{\circ} 28^{\prime} 43,339^{\prime \prime} \mathrm{E} / 1^{\circ} 16^{\prime} 34,164^{\prime \prime} \mathrm{N}$ \\
\hline 6 & Riparian & Hutan sekunder riparian & 6 & 21,01 & 3,75 & $109^{\circ} 28^{\prime} 23,658^{\prime \prime} \mathrm{E} / 1^{\circ} 16^{\prime} 26,743^{\prime \prime N}$ \\
\hline \multicolumn{4}{|c|}{ Jenis-jenis Mamalia } & \multicolumn{3}{|c|}{ seluruh lokasi pengamatan, jenis-jenis } \\
\hline & Berdasaı & In hasil penelitiai & & \multicolumn{3}{|c|}{ tersebut adalah sebagai berikut: } \\
\hline
\end{tabular}

didapatkan empat jenis mamalia dari

Tabel 2. Jenis-jenis Mamalia yang Memanfaatkan Jambu Tangkalak Sebagai Pakan Types of Mammals that Utilize Bellucia Pentamera As Feed

\begin{tabular}{ccc}
\hline No & Nama jenis & Nama Ilmiah \\
\hline 1 & Kera Ekor Panjang & Macaca fascicularis \\
2 & Bajing Ekor Pendek & Sundasciurus lowii \\
3 & Bajing Tiga Warna & Callosciurus prevostii \\
4 & Bajing Kelabu & Callosciurus orestes \\
\hline
\end{tabular}

Jenis-jenis Aves

Berdasarkan hasil penelitian lokasi pengamatan, jenis-jenis tersebut didapatkan tujuh jenis aves dari seluruh adalah sebagai berikut:

Tabel 3. Jenis-jenis Aves yang Memanfaatkan Jambu Tangkalak Sebagai Pakan (Types of Aves that Utilize Bellucia Pentamera As Feed)

\begin{tabular}{ccc}
\hline No & Nama jenis & Nama Ilmiah \\
\hline 1 & Cica Ijo & Chloropsis sonnerati \\
2 & Cabe Bunga Api & Dicaeum trigonostigma \\
3 & Cicaeum trochileum \\
4 & Merbah Cerucuk & Pycnonotus goiavier \\
5 & Cica Daun & Chloropsis cochinchinensis \\
6 & Pleci Mata Putih & Zosterops palpebrosus \\
7 & Kelicap Jantung & Arachnothera crassirostris \\
\hline Perbandingan Data Hasil Tempat & wilayah bukit antara Area Kelola Vak 2 \\
Tumbuh Bukit & dengan area Hutan Sekunder di Kebun \\
Berdasarkan hasil pengamatan pada & Raya Sambas, pada Area Kelola Vak 2 \\
area perbandingan tempat tumbuh & ditemukan tiga jenis aves yaitu Cica Ijo \\
jambu tangkalak yang berada pada & dengan nilai rata-rata perjumpaan 2,5,
\end{tabular}


Cabe Bunga Api 3 dan Cica Daun 0,5. Daerah Hutan Sekunder ditemukan tiga jenis aves yaitu Cica Ijo dengan nilai rata-rata perjumpaan 1, Merbah Cerucuk memiliki nilai 1 , dan untuk jenis Cica Daun dengan nilai perjumpaan 3 .

Hasil yang diperoleh untuk perbandingan jenis mamalia yang ditemukan pada Area Kelola Vak 2 terdapat tiga jenis yaitu Kera Ekor Panjang dengan nilai rata-rata perjumpaan 0,5, Bajing Ekor Pendek dengan nilai 2 dan Bajing Tiga Warna dengan nilai 1. Daerah lokasi Hutan Sekunder hanya ditemukan satu jenis mamalia yaitu Bajing Ekor Pendek dengan nilai rata-rata perjumpaan 3 . Jenis yang sama ditemukan di kedua lokasi yang diamati yaitu jenis aves Cica ijo dengan nilai perjumpaan yang berbeda, untuk Area Kelola Vak 2 dengan nilai 2,5 sedangkan Hutan Sekunder 1, jenis Cica Daun pada Area Kelola Vak 2 dengan nilai 0,5 sedangkan Hutan Sekunder 3. Mamalia yang ditemukan di kedua lokasi yang diamati yaitu jenis Bajing Ekor Pendek dengan nilai rata-rata perjumpaan 2 untuk Area Kelola Vak 2 dan 3 untuk daerah Hutan Sekunder.
Jenis aves Cica Ijo ditemukan di dua lokasi pengamatan dengan komposisi makan buah masak dan menempati bagian ruang tajuk atas tengah dan bagian bawah, Cica Daun juga ditemukan di dua lokasi pengamatan dengan komposisi makan bagian buah masak dan mengkal dengan menempati bagian ruang saat makan pada bagian tajuk tengah. Jenis aves yang hanya ditemukan di Area Kelola Vak 2 yaitu Cabe Bunga Api dengan komposisi makan pada bagian buah masak dan menempati ruang tajuk tengah dan bawah, sedangkan jenis aves yang ditemukan hanya pada Hutan Sekunder yaitu jenis Merbah Cerucuk dengan komposisi makan bagian buah masak dan pada bagian tajuk tengah.

Mamaila yang ditemukan pada kedua lokasi pengamatan adalah jenis Bajing Ekor Pendek dengan komposisi makan bagian buah masak dan mengkal serta berada pada ruang tajuk atas, tengan dan bagian bawah. Jenis mamalia yang ditemukan pada Area Kelola Vak 2 terdapat jenis Kera Ekor Panjang dan Banjing Tiga Warna yang masing masing memanfaatkan buah masak sebagai pakan dan menempati ruang tajuk bagian tengah (Tabel 4).

\section{Tabel 4. Nilai Perbandingan Rata-rata Perjumpaan pada Tempat Tumbuh Bukit} (Value of Average Comparison of Encounters at the Hill Growing Place)

\begin{tabular}{|c|c|c|c|c|}
\hline \multirow{2}{*}{ Nama Jenis } & \multicolumn{2}{|c|}{ Nilai Rata-rata Perjumpaan } & \multirow{2}{*}{ Komposisi Makan } & \multirow{2}{*}{ Ruang } \\
\hline & Vak 2 & Hutan Sekunder & & \\
\hline Cica Ijo & 2,5 & 1 & Buah Masak & Tajuk Atas, Tengah dan Bawah \\
\hline Cica Daun & 0,5 & 3 & Buah Masak dan Mengkal & Tajuk Tengah \\
\hline Kera Ekor Panjang & 0,5 & & Buah Mengkal & Tajuk Tengah \\
\hline Bajing Ekor Pendek & 2 & 3 & Buah Masak dan Mengkal & Tajuk Atas, Tengah dan Bawah \\
\hline
\end{tabular}


Berdasarkan hasil yang diperoleh jenis aves yang dijumpai pada Area Kelola dan Area Hutan Sekunder masing-masing memanfaatkan bagian buah dari jambu tangkalak. Nugroho (2015) menyatakan burung pemakan buah-buahan merupakan kelompok yang umum dijumpai di daerah hutan sekunder. Mamalia yang di temukan di dua lokasi pengamatan dari jenis Kera Ekor Panjang dan jenis bajing memanfaatkan jambu tangkalak sebagai pakan pada bagian buah, hal ini sesuai dengan pernyataan Anggrita (2017) bahwa beberapa jenis bajing memiliki karakteristik pakan yang hampir sama dengan Lutung Jawa dan Kera Ekor Panjang (Macaca fascicularis), kerena mamalia tersebut mampu memakan pucuk dan buah berbagai jenis vegetasi pohon yang berada di atas ketinggian yang tumbuh di daerah perbukitan.

Perbandingan Data Hasil Tempat

Tumbuh Kaki Bukit

Berdasarkan hasil pengamatan pada area perbandingan tempat tumbuh jambu tangkalak yang berada pada wilayah kaki bukit antara Area Kelola Vak 1 dengan area Hutan Sekunder di Kebun Raya Sambas, pada Area Kelola Vak 1 ditemukan dua jenis aves dengan nilai rata-rata perjumpaan Cabe Jawa 1 dan Cica Daun dengan nilai 3,5. Area Hutan Sekunder ditemukan dua jenis aves dengan nilai rata-rata perjumpaan Cabe Bunga Api 2 dan Merbah Cerucuk 3,5 .

Hasil yang di peroleh untuk perbandingan jenis mamalia yang ditemukan pada Area Kelola Vak 1 terdapat dua jenis mamalia dengan nilai rata-rata perjumpaan Kera Ekor Panjang 1 dan Bajing Kelabu dengan nilai 3,5 sedangkan untuk Area Hutan Sekunder hanya di temukan satu jenis mamalia Bajing Kelabu dengan nilai rata-rata 1,5. Hasil diatas menunjukan persamaan jenis yang dijumpai dari kedua tempat tumbuh kaki bukit antara Area Kelola dangan Area Hutan sekunder yaitu jenis mamalia Bajing Kelabu.

Area Kelola Vak 1 terdapat dua jenis aves yaitu Cabe Jawa dengan komposisi makan bagian buah masak dan berada pada ruang tajuk tengah, untuk jenis Cica Daun memakan buah masak dan mengkal dan berada pada ruang tajuk atas, tengan dan bagian bawah. Tempat tumbuh Hutan Sekunder terdapat jenis Cabe Bunga Api yang memanfaatkan bagian buah masak dan mengkal serta menempati ruang tajuk tengah dan bawah, untuk jenis Merbah Cerucuk hanya memakan buah masak dan menempati ruang bagian tajuk artas, tengah, dan bawah.

Mamalia yang ditemukan di kedua lokasi pengamatan dengan jenis Bajing Kelabu dengan memanfaatkan bagian buah masak dan mengkal derta berada pada bagian tajuk atas,tengah dan bagian bawah. Kera Ekor Panjang hanya ditemukan pada Area Kelola Vak 1 berada pada bagian tajuk atas dan tengah dan mengkonsumsi bagian buah masak (Tabel 5). 
Tabel 5. Nilai Perbandingan Rata-rata Perjumpaan pada Tempat Tumbuh Kaki Bukit (Value of Average Comparison of Encounters at the Place of Growing Hill Feet)

\begin{tabular}{|c|c|c|c|c|}
\hline \multirow{2}{*}{ Nama Jenis } & \multicolumn{2}{|c|}{ Nilai Rata-rata Perjumpaan } & \multirow{2}{*}{ Komposisi Makan } & \multirow{2}{*}{ Ruang } \\
\hline & Vak 1 & Hutan Sekunder & & \\
\hline Cabe Jawa & 1 & & Buah Masak & Tajuk Tengah \\
\hline Cica Daun & 3,5 & & Buah Masak dan Mengkal & Tajuk Atas, Tengah dan Bawah \\
\hline Kera Ekor Panjang & 1 & & Buah Masak & Tajuk Atas dan Tengah \\
\hline Bajing Kelabu & 3,5 & 1,5 & Buah Masak dan Mengkal & Tajuk Atas, Tengah dan Bawah \\
\hline Cabe Bunga Api & & 2 & Buah Masak dan Mengkal & Tajuk Tengah dan Bawah \\
\hline Merbah Cerucuk & & 3,5 & Buah Masak & Tajuk Atas, Tengah dan Bawah \\
\hline
\end{tabular}

Area kaki bukit Hutan Sekunder dan Area Kelola diperoleh jenis-jenis aves pemakan buah jambu tangkalak, tegakan jambu tangkalak menyediakan buah yang dapat dimanfaatkan oleh burung sebagai pakan, hal ini sesuai dengan pernyataan Dewi et al. (2007) bahwa vegetasi dimanfaatkan oleh burung sebagai habitat untuk bersarang, beristirahat, mencari makan, berkembangbiak dan lainnya, serta 30$50 \%$ burung tropis menggantungkan pakannya pada buah (Putri, 2015). Mamalia yang ditemukan di area kaki bukit yaitu Kera Ekor Panjang dan jenis Bajing kelabu yang memanfaatkan buah janbu tangkalak untuk dikosumsi dikarenakan tegakan tersebut dalam kondisi berbuah, sesuai dengan pernyataan pola aktifitas mamalia pada stratifikasi atas menunjukan bahwa ketersediaan sumber daya pakannya sedang berlimpah (Gunawan et al, 2008).

\section{Perbandingan Data Hasil Tempat}

\section{Tumbuh Riparian}

Berdasarkan hasil pengamatan pada area perbandingan tempat tumbuh jambu tangkalak yang berada pada wilayah riparian antara Area Kelola Taman Tematik dengan area Hutan
Sekunder di Kebun Raya Sambas, Area

Kelola Taman Tematik ditemukan enam jenis aves yang memanfaatkan jambu tangkalak sebagai pakan yaitu jenis Cica Ijo dengan nilai rata-rata perjumpaan 0,66, Cabe Bunga Api 4,33, Cica Daun 1, Cabe Jawa 0,66, Merbah Cerucuk 2,33, Kecilap Jantung 0,66. Sedangkan untuk Area Hutan Sekunder ditemukan hanya dua jenis aves yaitu Pleci Mata Putih dengan nilai rata-rata perjumpaan 0,5 dan jenis Merbah Cerucuk dengan nilai 2,5.

Perbandingan data yang menunjukan perbedaan antara daerah tempat tumbuh jambu tangkalak, di daerah riparian pada data diatas jenis mamalia yang memanfaatkan jambu tangkalak sebagai sumber pakan untuk Area Kelola Taman Tematik terdapat jenis Kera Ekor Panjang dengan nilai rata-rata perjumpaan 1 dan jenis Bajing Kelabu dengan nilai 1. Sedangkan untuk daerah Hutan Sekunder hanya ditemukan satu jenis mamalia yaitu Bajing Ekor Pendek dengan nilai ratarata perjumpaan 3 .

Merbah Cerucuk adalah jenis aves yang ditemukan pada dua lokasi pengamatan yang mengkonsumsi bagian buah masak dan mengkal pada 
posisi tajuk atas, tengah, dan bawah. Jenis aves pada Area Kelola Taman tematik Cica Ijo, Cabe Bunga Api dan Cabe jawa masing-masing memanfaatkan bagian buah masak dan menempati ruang tajuk tengah dan bawah untuk jenis Cabe Bunga Api dan Cabe Jawa sedangkan Cica Ijo pada bagian tajuk atas dan bagian tengah. Cica Daun memanfaatkan bagian buah masak dan mengkal pada ruang tajuk atas dan tengah, jenis Kecilap Jantung adalah jenis yang menanfaatkan bagian bunga yang berada pada ruang tajuk tengah. Hutan Sekunder Riparian terdapat jenis Pleci Mata Putih yang memanfaatkan buah masak dan berada pada bagian tajuk tengah.

Kera Ekor Panjang dan Bajing Kelabu masing-masing memanfaatkan bagian buah masak dan mengkal serta menempati bagian tajukatas dan tengah yang berada pada Area Kelola Taman Tematik. Bajing Ekor Pendek adalah jenis mamalia yang memanfaatkan buah masak dan mengkal sebagi pakan dan berada pada tajuk tengah dan bawah di Hutan sekunder Riparian (Tabel 6).

Tabel 6. Nilai Perbandingan Rata-rata Perjumpaan pada Tempat Tumbuh Riparian (Value of Average Meeting Comparison in Riparian Growing Places)

\begin{tabular}{|c|c|c|c|c|}
\hline \multirow{2}{*}{ Nama Jenis } & \multicolumn{2}{|c|}{ Nilai Rata-rata Perjumpaan } & \multirow{2}{*}{ Komposisi Makan } & \multirow{2}{*}{ Ruang } \\
\hline & Taman Tematik & Hutan Sekunder & & \\
\hline Cica Ijo & 0,66 & & Buah Masak & Tajuk Atas dan Tengah \\
\hline Cabe Bunga Api & 4,33 & & Buah Masak & Tajuk Tengah dan Bawah \\
\hline Cica Daun & 1 & & Buah Masak dan Mengkal & Tajuk Atas dan Tengah \\
\hline Cabe Jawa & 0,66 & & Buah Masak & Tajuk Tengah dan Bawah \\
\hline Merbah Cerucuk & 2,33 & 2,5 & Buah Masak dan Mengkal & Tajuk Atas, Tengah dan Bawah \\
\hline Kelicap Jantung & 0,66 & & Bunga & Tajuk Tengah \\
\hline Kera Ekor Panjang & 1 & & Buah Masak dan Mengkal & Tajuk Atas dan Tengah \\
\hline Bajing Kelabu & 1 & & Buah Masak dan Mengkal & Tajuk Atas dan Tengah \\
\hline Pleci Mata Putih & & 0,5 & Buah Masak & Tajuk Tengah \\
\hline Bajing Ekor Pendek & & 3 & Buah Masak dan Mengkal & Tajuk Tengah dan Bawah \\
\hline
\end{tabular}

Tempat tumbuh jambu tangkalak Area reparian yang diamati menjukan hasil jenis burung yang ditemukan sebagian besar adalah pemakan buah, namun dapat dijumpai satu jenis burung yang memakan nektar bunga jambu tangkalak yaitu jenis Kecilap Jantung (Arachnothera crassirostri), hai ini sesuai dengan pernyataan bahwa beberapa jenis burung seperti spesies burung dari famili Nectariniidae dan Pycnonotidae memilih habitat dan sering beraktifitas di pepohonan yang menghasilkan nektar atau buah sebagai pakan (Nababan et al, 2015).
Mamalia yang ditemukan di daerah riparian secara umum memanfaatkan buah sebagi sumber pakannya, hal ini menujukan bahwa tegakan yang diamati cukup menyediakan buah untuk dikosumsi oleh satwa yang diamati, sesuai dengan pernyataan jenis mamalia yang ditemukan pada habitat rawa dan dataran rendah riparian berkaitan dengan ketersediaan pakan yang cukup melimpah dan tersedianya walfare factors yang lain yang terdapat pada habitat tersebut (Santosa $e t$ al. 2008).

Komposisi Makan 
Berdasarkan hasil komposisi makan (Tabel 4,5dan 6) menunjukan secara umum jenis burung yang di jumpai adalah pemakan buah memakan bagian buah jambu tangkalak yang masak dan mengkal, hai ini dikarenakan beberapa faktor karakrteristik yang dimiliki oleh buah jambu tangkalak. Kondisi daging buah yang lembut saat mengkal dan masak menjadikan kondisi yang sesuai untuk dikosumsi satwa, hal ini didukung pernyataan Jarulis et al. (2013) bahwa beberapa jenis burung menyukai bagian buah berdaging yang memiliki karakteristik lembut sebagai pakannya, dibandingkan dengan daging buah yang masih keras walaupun pada jenis buah yang sama.

Faktor lain yang mempengaruhi dikonsumsinya buah yang masak dan mengkal jambu tangkalak oleh burung dan mamalia selain tekstur adalah warna dan rasa, warna saat buah menuju fase masak adalah kuning dan memiliki rasa manis keasaman saat masak sempurna. Warna yang mencolok (merah, kuning, putih dan lain-lain) pada bagain tumbuhan baik bagian bunga atau buah, adalah salah satu daya tarik dari tumbuhan sebagai sarana penyerbukan atau penyebaran biji yang dibantu oleh makhluk lain (Gitta ed al, 2012).

Warna dari bunga jambu tangkalak berwarna putih menjadi daya tarik jenis Arachnothera crassirostris memanfaatkan bagian bunga sebagai pakannya. Menurut data Elina ed al, (2017) mamalia pemakan buah sebagian menyukai buah yang masak dikarenakan memiliki rasa yang lebih kaya dibandingkan buah yang masih muda.
Jenis burung genus Dicaeum dan Chloropsis yang ditemukan adalah termasuk dalam jenis yang memanfaatkan jambu tangkalak serbagai makanan favorit (sering dikunjungi), karena memiliki daging buah yang lembut sesuai dengan karakteristik jenis pakannya (Widodo, 2006). Kera Ekor Panjang dan tiga jenis bajing yang di jumpai pada penelitan ini memanfaatkan jambutangkalak sebagai pakan sampingan, karena secara umum mamalia hutan sekunder memiliki kebegaraman pakan yang beragam sesuai kondisi pakan yang tersedia di lingkungannya (Pradhany ed al, 2016).

Ruang

Hasil penelitian yang dilakukan menunjukan satwa yang ditemukan baik mamalia maupun aves yang memanfaatkan jambu tangkalak hanya berada pada bagain tajuk saja, tidak ditemukan pada bagian latai tegakan dan bagian lainnya. Kondisi dilapangan secara umum memiliki tegakan jambu tangkalak yang berbuah hampir di semua bagian tajuk, baik pada atas, tengah dan bawah, hal ini yang menyebabkan aves dan mamalia yang diamati dapat dijumpai memanfaatkan buah sebagai pakan pada bagain tajuk saja. Wisnubudi (2009) menyatakan aktifitas satwa mencari makan dipengaruhi oleh letak dan kondisi dari keberadaan sumber pakan yang tersedia di lingkungannya.

Jenis aves dan mamalia yang ditemukan dalam penelitian adalah satwa diurnal yang tergolong aktif beraktifitas (bergerak), aktifitas satwa dipengaruhi oleh kondisi lingkungannya. Widodo dan Sulistiadi (2016) beberapa faktor yang 
menentukan keberadaan burung adalah ketersediaan pakan, tempat beristirahat, bermain, kawin, bersarang, bertengger, dan berlindung. Nasir ed al.(2017) menyatakan bahwa secara alami jenisjenis satwa aktif seperti tupai memanfaatkan bagain tajuk-tajuk pohon untuk pohon untuk mencari makan, istirahat, dan berpindah tempat, serta meminimalisir resiko yang mengngancam pada lantai hutan (predator).

Persaingan jenis pakan dan ruang yang sama dari jenis satwa yang bebeda pada penelitian ini secara pengamatan di lapangan terminimalisir oleh keadaan satwa itu sendiri, karena rentang waktu saat suatu jenis memanfaatkan jembu tangkalak secara umum berbeda-beda tidak dalam waktu yang bersamaan. Surya et al. (2013) menyatakan adanya pemanfaatan waktu yang berbeda oleh hewan diurnal termasuk burung merupakan upaya mereka dalam mengurangi kompetisi antar jenis dalam pemanfaatan sumberdaya yang sama.

Hasil penelitian menunjukan bahwa secara umum Area Hutan Sekunder memiliki tingkat perjumpaan jenis satwa aves dan mamalia lebih sedikit dibandingkan dengan Area Kelola. Data menujukan perbandingan terbalik dengan konsep yang di kemukakan Tortosa (2000) struktur vegetasi dan ketersediaan pakan pada habitat merupakan faktor utama yang mempengaruhi keanekaragaman jenis di suatu habitat, sehingga habitat dengan variasi vegetasi lebih beragam akan memiliki keanekaragaman jenis satwa yang lebih tinggi dibandingkan dengan habitat yang memiliki sedikit jenis vegetasi.

Faktor berpengaruh pada hasil penelitian ini adalah keragaman jenis pakan yang tersedia itu sendiri, dikarenakan kondisi lapangan pada saat penelitaian adalah awal musim hujan sehingga banyak jenis tumbuhan lain yang menghasilkan buah tidak hanya jambu tangkalak. Kondisi saat penelitian ini diduga penyebab Area Kelola lebih banyak jenis satwa yang ditemukan karena wilayah ini hanya tersedia pohon pakan yang terbatas karena proses pengeloaanya terdapat penebangan pohon tertentu, sedangkan Hutan Sekunder memiliki jenis jenis pakan yang lebih beragam untuk di kosumsi satwa. Tews et al. (2004) menyatakan hal yang sama yaitu beragamnya jenis vegetasi yang terdapat pada suatu habitat mendukung ketersediaan pakan bagi satwa, sehingga dengan beragamnya jenis vegetasi, maka satwa akan mendapatkan pilihan yang lebih banyak untuk memilih jenis pakan, sehingga pada kondisi lapangan yang ada satwa di daerah Hutan Sekunder tidak fokus hanya memanfaatkan jambu tangkalak namun juga tumbuhan lain yang sedang berbuah.

\section{KESIMPULAN}

1. Hasil data perbandingan dari ketiga tempat tumbuh jambu tangkalak (bukit, kaki bukit, riparian) antara Area Kelola dangan Hutan Sekunder menujukan bahwa Area Kelola memiliki jenis yang ditemukan lebih banyak dibandingkan Hutan Sekunder.

2. Berdasarkan hasil di lapangan jenis aves yang memanfatkan jambu 
tangkalak di Kebun Raya Sambas ditemukan tujuh jenis yaitu Cica Ijo, Cabe Bunga Api, Cabe Jawa, Cerocok, Cica Daun, Pleci Mata Putih, dan Kecilap Jantung.

3. Berdasarkan hasil di lapangan jenis mamalia yang memanfaatkan jambu tangkalak di Kebun Raya Sambas ditemukan empat jenis yaitu Kera Ekor Panjang, Bajing Ekor Pendek, Bajing Kelabu, dan Bajing Tiga Warna.

4. Sebagian besar jenis satwa yang ditemukan memanfaatkan jambu tangkalak sebagai pakan pada bangain buah masak dan mengkal, hanya satu jenis burung Kecilap Jantung yang memanfaatkan nektar bunga jambu tangkalak.

5. Secara umum satwa mengunakan ruang tajuk tegakan atas, tengah dan bawah dikarenakan bagian tersebut adalah tempat tersedianya buah jambu tangkalak.

\section{SARAN}

Berdasarkan hasil dan pembahasan pada penelitian ini diharapkan dapat menjadi salah satu sarana pendukung konservasi baik satwa maupun jenis tegakan jambu tangkalak. Saran kedepannya dapat dilakukan penelitian pada saat kondisi lapangan tidak musim buah, karena penelitian ini dilakukan pada saat awal musim hujan dan musim buah (tumbuhan lain), dengan perbandingan karakteristik jambu tangkalak yang berbuah hampir di sepanjang musim, serta pengamatan satwa nokturnal yang memafaatkan jambu tangkalak di Kebun Raya Sambas.

\section{UCAPAN TERIMA KASIH}

Terima kasih kepada beasiswa Outreaching Bidik Misi yang menfasilitasi saya dalam pendanaan dan pembinaan kuliah, serta terima kasih untuk pengelola Kebun Raya Sambas dalam menyediakan tempat serta pendampingan lapangan dalam proses penelitian.

\section{DAFTAR PUSTAKA}

Anggrita, Nasihin L, Nendrayan Y. 2017. Keanekaragaman Jenis dan Karakteristik Habitan Mamalia Besar di Kawasan Hutan Bukit Bahoror Desa Cipaten Kecamatan Hantar Kabupaten Kuningan. Wanaraksa 11(1).

Asy'ari. M. dan Karim A.A. 2012. Pengukuran Kayu. Fakultas Kehutanan, Universitas Lambung Mangkurat. Banjarbaru.

Dewi S.R, Mulyani Y. Santosa Y. 2007. Keanekaragaman Jenis Burung di Beberapa Tipe Habitat Taman Nasional Gunung Ceremai. Media Konservasi 12(3).

Elina D, Nasution E.K, Indrawan. 2017. Tingkah Laku Lutung Jawa Trachypithecus auratus di Kawasan Pancuran 7 Baturaden Gunung Selamet Jawa Tengah. Scripta Biologica. 4(02) : 125-129

Gitta A, Masy'ud B, Suzanna E. 2012. Aktifitas Harian dan Prilaku Makan Burung Kakatua Kecil Jambul Kuning (Cacatua Sulphurea Sulphurea Gmelin, 1788) di Penangkaran. Media Konservasi. 17(1) : 23-24

Gunawan, Kartono A.P, Maryanto I. 2008. Keanekaragaman Mamalia Besar Berdasarkan Ketinggian Tempat di Taman Nasional Gunung Ciremai. Jurnal Biologi Indonesia 04(5): 32133. 
Jarulis, Meidian A, Kamilah S.N. 2013. Komposisi Guild Burung-Burung di Kawasan Hutan Taman Wisata Alam Seblat Kabupaten Bengkulu Utara. Konservasi Hayati. 09(02) : 18-24

Nababan B.R.R, Setiawan A, Nurcashyani N. 2015. Keanekaragaman Jenis Burung di Lahan Basah Way Pegadungan Desa Rajawali Kecamatan Bandar Surabaya Kabupaten Lampung Tengah. Jurnal Sylva Lestari 03(1): 71-80

Nasir M, Amira Yulia, Mahmud A.H. 2017 Keanekaragaman Jenis Mamalia Kecil (Famili Muridae) pada Tiga Habitat yang Berbeda di Lhokseumawe Provinsi Aceh. BioLeuser. 1(1) : 1-6

Nugroho A.S. Anis T, Ulfah M. Analisis Keanekaragaman Jenis Tumbuhan Berbuah di Hutan Lindung Surokonto, Kendal, Jawa Tengah dan Potensinya Sebagai Kawasan Konservasi Burung. Pros Sem Nas Masy Biodiv Indon 01(3):472-476.

Pradhany R.C, Widyastuti S.K, Wandia N. 2016. Aktivitas Harian Monyet Ekor Panjang (Macaca fascicularis) yang telah divasektomi di Wenara Wana Ubud. Indonesia Medicus Veterinus. 5(3) : 240-247

Putri I.A.S.L.P 2015. Pengaruh Kekayaan Jenis Tumbuhan Sumber Pakan Terhadap Keanekaragaman Burung Herbivora di Taman Nasional Bantimurung Bulusaraung, Sulawesi Selatan. Pros Sem Nas Masy Biodiv Indon 01(3):607-614

Santosa Y, Ramadhan E.P, Rahman D.A. 2008. Studi Keanekaragaman Mamalia Pada Beberapa Tipe Habitat di Stasiun Penelitian Pondok Ambung Taman Nasional Tanjuung
Puting Kalimantan Tengah. Media Konservasi 13(3):1-7.

Tews J, Brose U, Grimm V, Tielborger K, Wichmann MC, Schwager M, and Jeltsch F. 2004. Animal species diversity driven by habitat heterogeneity/diversity: The importance of keystone structure. Journal of Biogeography 31: 79-92.

Tortosa F.S. 2000. Habitat Selection by Flocking Wintering Common Cranes (Grus grus) at Los Pedroches Valley, Spain. Etologia 8: 21-24.

Widodo W. 2006. Kemelimpahan dan Sumber Pakan Burung-burung di Taman Nasional Manusela, Seram, Maluku Tengah. Biodiversitas. 07(1) : 54-58

Widodo W dan Sulystiadi E. 2016. Pola Distribusi dan Dinamika Komunitas Burung Di Kawasan Cibinong Science Center. Jurnal Biologi Indonesia. 12 (1) : 145-158

Wijayanto N. dan Rifa'i M. 2010. Pertumbuhan Tanaman Pokok Gmelina (Gmelina arborea Roxb.) pada Beberapa Pola Agroforestri di Desa Cikanyere, Kecamatan Sukaresmi, kabupaten Cianjur. Jurnal Silvikultur Tropika 01(1): 2934

Wisnubudi G. 2009. Penggunaan Strata Vegetasi oleh Burung di Kawasan Wisata Taman Nasional Gunung Halimun-Salak. Vis Vitalis. 02 (02) 